\title{
Indicators Affecting Vidzeme Region Smart Development
}

\author{
Sarmite Rozentale, Aigars Andersons \\ Institute of Social, Economic and Humanities Research of Vidzeme University of Applied Sciences Address: \\ Cesu street 4, Valmiera LV-4110, Latvia
}

\begin{abstract}
The study aims to determine the main indicators of rural smart development concept for territorial development analysis and decision-making in Vidzeme region (Latvia). In the framework of the study the theoretical literature and planning documents were analysed, focusing on the indicators of rural areas and sustainable development. For a long time the development was associated primarily with the economic growth - GDP, employment and income growth. In recent years, the economic dimension is supplemented with social, environmental, cultural and political aspects. A holistic approach interprets close relations and balanced integration between the economic, social, political, ecological and cultural dimensions of local and regional development. Such approach requires the search for new indicators that describe the development of rural areas and are directly relevant to each individual area. The results present that in the development of Vidzeme smart specialization, the local governments and the state has the greatest impact. It is most affected by the local government's capacity to develop cooperation with residents and entrepreneurs, and a stable and sustainable economic situation in the country.
\end{abstract}

Keywords: smart development, sustainable development, indicators.

\section{INTRODUCTION}

In public administration, the development towards evidence-based decision-making in economic sectors is being favoured. Informative evidence must become the centre of the policy development and implementation, but data quality is becoming one of the key prerequisites for this process.

From 2014 to 2018 within a subproject of National Research Program EKOSOC LV 5.2.3., the prerequisites of smart development of Latvian rural areas were examined in order to create a knowledge base for decision-making for economic transformation in the direction of smart development.

The aim of the research includes smart development concept which is defined as the main base for the economic development of a smart community. This model is based on several concepts - the promotion of sustainable development, an attractive environment for new businesses, innovation in business.

Europe 2020 strategy for a smart, sustainable and inclusive growth relies on three priorities, which are complementary to each other:

- Smart growth - the economic development based on knowledge and innovation;

- Sustainable growth - the promotion of more resource-efficient, greener and more competitive economy

- Inclusive growth - fostering an economy with a high employment level and ensuring social and territorial cohesion [1]
The compliance with the principles of sustainable development as the basic method for encouraging the development of Latvian municipal territories has been defined in a number of top-level laws of Latvia in the recent decades, of which the most important are "Regional Development Law" [2], "Spatial Development Planning Law" [3] "Development Planning System Law" [4], "Environmental Protection Law" [5], the Law "On local governments" [6], as well as a number of regulations of the Cabinet of Ministers and local governments related to the above mentioned laws.

Unfortunately, the principles and guidelines defined for the strategy "Europe 2020" are only partially observed in the strategy "Latvia 2030". According to Latvian and foreign studies [7], the requirements and regulations of the strategy "Latvia 2030 " include less than $50 \%$ of the regulations of the strategy "Europe 2020". This means that in modelling a smart, sustainable, inclusive development process of Vidzeme region municipalities until 2030, the criteria and indicator range has to be significantly complemented in order to obtain the research results that are as close as possible to the reality.

In the scientific literature there is no single set of indicators that characterize the smart, sustainable, inclusive development. More common are indicators that characterize innovations, such as the Innovation Union Scoreboard [8].

In the research on the existing experience and tendencies in the smart, sustainable development process of territories, several foreign authors' research

ISSN 1691-5402

(C) Rezekne Academy of Technologies, Rezekne 2017 http://dx.doi.org/10.17770/etr2017vol1.2604 
emphasizes the need to more extensively use the methods which are based on a quantitative data analysis, not just descriptive qualitative data analysis[7], [9]. In recent studies, a great importance in the development of rural areas is attached to local resources. This includes decentralised governance; collaboration of all stakeholders, different innovative operational approaches based on the identity of the place and highly developed human capital. Rural space development is determined by the ideas, activities and initiatives of the local residents promoting regional diversity and quality of services.

Both qualitative and quantitative indicators should be applied to regional development models. Different theories and development indices and indicators are applied in various countries. Most often, they are divided into four dimensions: economic, social, environmental-institutional and political.

This study specifically analyses the impact of institutional indicators since a number of respectable researchers have considered them as important and included them in their work. Institutional and political indicators include the opportunity to participate in decision-making, transparent work of a local government, sustainable authority and business management [10].

The study aims at measuring the impact of institutional indicators in Vidzeme region by defining impact instruments and their significance for each dimension.

\section{MATERIALS AND METHODS}

The methodological basis of the research consists of 3 research methods: the analysis of sustainable development strategies of Vidzeme municipalities, the survey of residents (n-250), AHP method for identifying the key factors of rural development for the concept of smart area development.

Evaluating the published strategic and operational planning documents of Vidzeme municipalities, it can be concluded that sustainability is usually referred to as a goal in itself, a result of a certain process, although it should be mostly regarded as an evaluation mechanism for a variety of other real-life processes, and a set of tools that can determine whether a particular region has the smart, sustainable development prospects and to what extent. The largest problem in the process of determining the sustainability is the assessment of such indicators which are characterized as "intangible measurements" - they are not found as numerical values in annual reports or statistical reports of municipalities, but at the same time they can be significant indicators that may indicate the future prospects [11]. Therefore, there is currently a variety of assessment methods practically developed for measuring the smart sustainable development indicators, but so far none of them has become a worldwide recognized standard or a generally accepted measurement system.

At the moment it is very important for the municipalities of Vidzeme region to identify the impact indicators in order to determine whether they function in accordance with the smart, sustainable development principles. After determining and measuring the weak points of a municipality, it is possible to significantly increase the operational efficiency. During the study, the authors summarized the institutional indicators of the smart, sustainable development by analysing the sustainable development strategies of the municipalities of Vidzeme region and by using the in-depth interviews of local government employees acquired during the preceding stage of the research. The employees were asked a question: Which indicators, in your opinion, have affected the economic activity in the territory administered during the last five years? The summary of the results is shown in Table 1 .

Table 1

Labels for the Operation of Indicators

\begin{tabular}{|c|c|}
\hline Indicators & Label \\
\hline \multicolumn{2}{|l|}{ State as an institution } \\
\hline $\begin{array}{l}\text { a) Maintaining favourable economic situation in the } \\
\text { country }\end{array}$ & V1 \\
\hline b) Maintaining the stability of legislation & $\mathrm{V} 2$ \\
\hline $\begin{array}{l}\text { c) Development of a tax system that promotes the } \\
\text { economic activity }\end{array}$ & V3 \\
\hline d) Ensuring the access to the EU funding & V4 \\
\hline $\begin{array}{l}\text { e) Successful operation of the financial equalization } \\
\text { fund }\end{array}$ & V5 \\
\hline f) Offers of earmarked subsidies & V6 \\
\hline \multicolumn{2}{|l|}{$\begin{array}{l}\begin{array}{l}\text { Local governments as local power structures } \\
\text { (deputies - employees) }\end{array} \\
\end{array}$} \\
\hline $\begin{array}{l}\text { a) The skills of a municipality/ town local } \\
\text { government to attract the EU structural funds and } \\
\text { use them successfully }\end{array}$ & $\mathrm{P} 1$ \\
\hline $\begin{array}{l}\text { b) Focused and concerted action of deputies in the } \\
\text { development and implementation of a } \\
\text { municipality/ town development strategy }\end{array}$ & $\mathrm{P} 2$ \\
\hline $\begin{array}{l}\text { c) The competence of local government staff in } \\
\text { municipality development planning and project } \\
\text { management }\end{array}$ & $\mathrm{P} 3$ \\
\hline $\begin{array}{l}\text { d) Municipality / town development programme } \\
\text { implementation results are systematically assessed } \\
\text { and residents are informed of this by way of direct } \\
\text { contact or through the local information sources }\end{array}$ & $\mathrm{P} 4$ \\
\hline $\begin{array}{l}\text { e) The local government maintains close working } \\
\text { contacts with local businesses, addressing the key } \\
\text { issues important to both sides }\end{array}$ & P5 \\
\hline $\begin{array}{l}\text { f) The local government creates favourable } \\
\text { conditions for the activities of NGOs and other } \\
\text { groups of the society, and actively involves them } \\
\text { in the discussion and implementation of important } \\
\text { development issues }\end{array}$ & P6 \\
\hline Communities living in the territory of a municipality & \\
\hline $\begin{array}{l}\text { a) The interest of local residents to take part in } \\
\text { solving practical issues of a municipality/ town by } \\
\text { active participation }\end{array}$ & K1 \\
\hline
\end{tabular}




\begin{tabular}{|l|l|l|}
\hline b) The readiness of municipality/ town residents for & $\mathrm{K} 2$ \\
economic activities in order to increase personal \\
income
\end{tabular}

The authors conducted a survey of Vidzeme region residents in order to obtain the real assessment of the population indicators, and the real and optimal impact in Vidzeme of three active elements - the state, local governments and residents.

The survey involved 252 residents of Vidzeme from all municipalities and different population groups. Within the survey the indicators were evaluated from a 3-dimensional perspective proposed by the authors, and with 6 indicators in each dimension (see Table 1). In the survey the participants were asked, first, to assess each indicator on a scale of 0-4, where 4 - high, 3 - medium, 2 - low, 1- negative, 0- no opinion, and, second, to evaluate the real and optimal impact of three active elements in Vidzeme region - the state, the local government and the population.

In order to measure the influence of the population, the local government, the state and the EU policies on these indicators, the Analytic Hierarchy Process (AHP) method was used (the author - Thomas L. Saaty). It is an expert method, based on carrying out an expertise (expert assessment obtaining procedure), and the evaluation of its results using validated mathematical methods [12].

The hierarchy of the problem elements is made from the top - the aim, through intermediate levels containing groups of criteria and criteria, a list of alternatives can be found on the lowest level. It is socalled dominance hierarchy. The process of hierarchy can be seen in Figure 1.

\begin{tabular}{|c|}
\hline - befining decision problem \\
\hline Dewopoing a conceptus framewor! \\
\hline Fetting up the detion hietarty \\
\hline Collecting data from experts \\
\hline Employing the par-wise comparison \\
\hline Estimating relative weights of elements \\
\hline Falculating the degee of consisteny \\
\hline Calculating the mind relathe weight \\
\hline
\end{tabular}

Fig. 1. AHP process
By using both of these methods, a qualitative analysis of the research object is achieved, including measurable qualitative indicators which significantly influence the development of the object, forecasting variants that can be ranked, grouping of different objects, indicators, ranking and prioritization, preparation of decisions.

The aim of the hierarchy analysis is the development of Vidzeme region smart specialization. 4 indicators were chosen: indicator A - the population impact characterized by activities of particular groups of residents in acquisition and dissemination of ideas of innovative changes, the involvement of residents in formal and non-formal education, residents' entrepreneurial ability and capacity, the use of residents' disposable resources for income generation; indicator B - the local government impact characterized by the skills of a local government to attract EU structural funds and use them successfully, the competence of employees in managerial decision-making and implementing for the municipality development, the role of a local government for effective use of resources; indicator $\mathrm{C}$ - the state impact characterized by maintaining a stable sustainable economic situation in the country, the state involvement in promoting innovative entrepreneurship, providing the availability of EU funding for the development of smart specialisation in the regions, a successful implementation of the financial equalisation and tax policy; indicator D the EU impact characterized by the influence of cohesion policy and its orientation towards reducing EU regional disparities, the promotion of innovative processes in collaboration with EU member states and regions, the EU strategy and the conditions for the development of entrepreneurship and innovation, creating conditions for regional specialisation and building competitiveness in the EU policy.

As a result of the hierarchy analysis, there are 4 choices for the smart specialisation of Vidzeme region: 1) smart governance, 2) smart resources (natural and environmental resources), 3) smart population, 4) smart economy. 4 professionals were chosen as experts representing a local government, an NGO, Vidzeme Nature Conservation Agency and a scientific institution.

\section{RESULTS AND DISCUSSION}

The operation of indicators referring to the state as an institution in the assessment of residents

The sums of the residents' assessment in the dimension of state as an institution are shown in Figure 2. The residents have pointed out that in the state dimension ensuring the availability of EU funding is operating the best. On the contrary, the least successful is the operation of the financial equalization fund. 


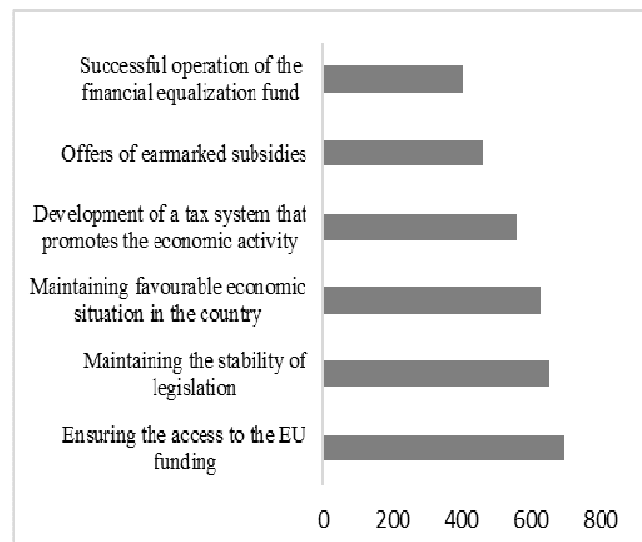

Fig.2. Operation assessment of indicators of state as institution Source: Results of residents' survey

The operation of indicators referring to a local government as a local power institution in the assessment of residents

The sum of the residents' assessment in the dimension of a local government as a local power institution are shown in Figure 3.

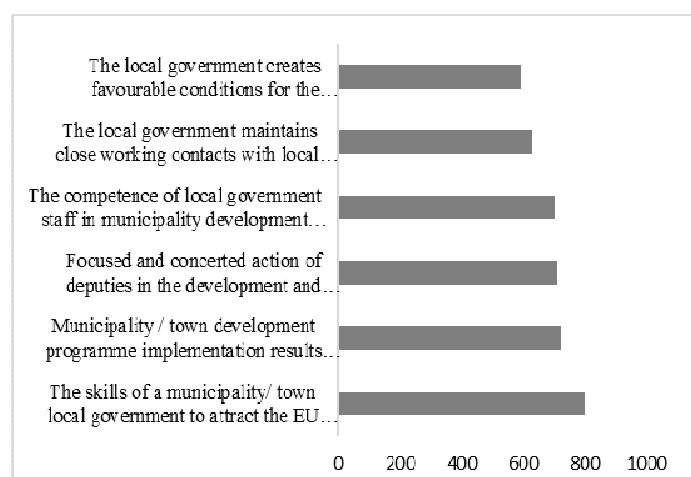

Fig.3. Operation assessment of the indicators of a local government as an institution

Source: Results of residents' survey

The residents have indicated that in the dimension of a local government, the most successfully operating indicators are the skills of a municipality or town local government to attract EU structural funds and use them successfully. In contrast, the least successful operation in the local government dimension is assigned to the ability of the municipality to create favourable conditions for the activities of NGOs and other groups of the society, actively involving them in the discussion and implementation of important development issues, the ability of the local government to maintain close working contacts with local businesses, addressing the key issues important to both sides.

The operation of indicators referring to communities living in the territory of a municipality in the assessment of residents.

The sums of the residents' assessment in the dimension of communities living in the municipality are shown in Figure 4.

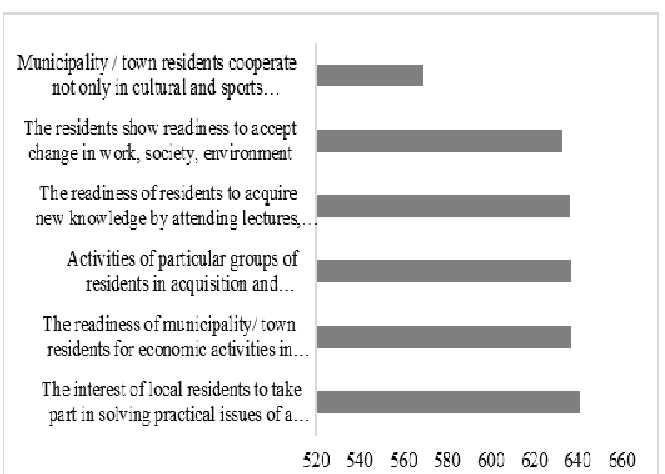

Fig.4. Operation assessment of the indicators of communities residing in the territory of a municipality

Source: Results of residents' survey

The residents have indicated that the most successful operation in the dimension of communities refers to the interest of local residents to take part in solving practical issues of a municipality/ town by active participation. On the contrary, the least successfully operating is the ability of municipality/ town residents to cooperate through the economic cooperation chains or even cooperatives, visible readiness to accept change in work, society, environment, the readiness of residents to acquire new knowledge by attending lectures, participating in seminars, joining courses.

On the whole, the municipality dimension has acquired the highest assessment of operation, but the state as an institution - the lowest assessment.

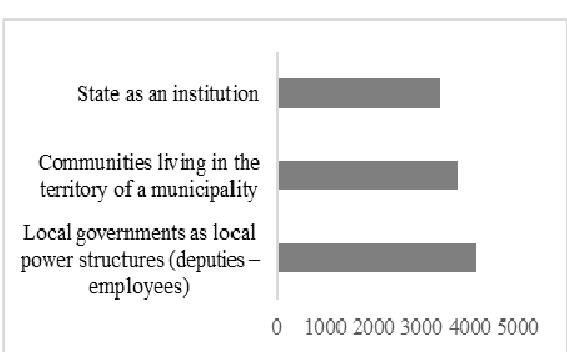

Fig 5. Operation assessment of the indicators of the state, the local government and communities

Source: Results of residents' survey

Residents assessed the state, local government and community real and optimal impact, giving weight or importance. The residents' assessment is shown in the Figure 6.

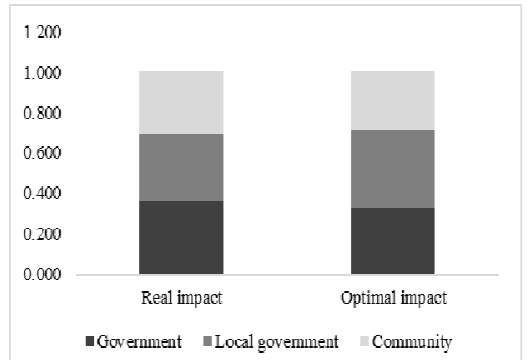

Fig 6. The assessment of the real and optimal impact of the state, the local government and communities. 
In reality the state as an institution has the greatest impact according to the residents' assessment, but the smallest impact - the community. By contrast, the optimal greatest impact should be by the local government, but the smallest - the community.

During the next step the hierarchy analysis was carried out. The hierarchy analysis model as well as the residents' survey measured the state, the local government and the population dimension, with an addition of the EU dimension.

Each dimension was divided into four impact tools (see Table 2)

Table 2

Impact Dimensions and Impact Tools

Population impact

a) Activities of particular groups of residents in acquisition and dissemination of innovative changes

b) Involvement of residents in formal and non-formal education

c) Residents' entrepreneurial ability and capacity

d) Use of residents' disposable resources for income generation

Local Government impact

a) Ability to attract EU structural funds and successfully use them

b) Employees competence in managerial decision-making and implementing for the good of municipality development

c) Ability to establish collaboration with residents and entrepreneurs

d) Ability to efficiently use resources

State impact

a) Stable and sustainable economic situation in the country

b) State involvement in implementing innovative entrepreneurship

c) Provision of the availability of the EU funding for the promotion of smart specialisation in the regions

d) Successful implementation of financial equalisation and tax policy

EU impact

a) Impact of the cohesion policy and orientation towards reducing the EU regional disparities

b) Promotion of innovative processes in the collaboration with EU member states and regions

c) The EU strategy and conditions for development of entrepreneurship and innovative activities

d) Creating conditions for regional specialisation and building competitiveness in the EU policy

The results of the hierarchy analysis are shown in Figure 7. The graph shows that the local government has the greatest impact on Vidzeme region smart specialization development - a proportion of 0.28 , and the state has the same impact. The EU impact proportion is 0.25 , but residents have the least impact proportion - 0.19. The impact of the local government is most affected, first, by its ability to establish collaboration with residents and entrepreneurs, second, by the employees' competence in managerial decision-making and implementing for municipality development, third, by its ability to efficiently use resources, fourth, by the ability to attract the EU structural funds and successfully use them.

The state impact is most affected, first, by maintaining a stable and sustainable economic situation in the country, second, by provision of availability of the EU funding for the promotion of smart specialisation in the regions, third, by a successful implementation of financial equalisation and tax policy, fourth, by the state involvement in implementing innovative entrepreneurship.

The EU impact is most affected, first, by creating conditions for regional specialisation and building competitiveness in the EU policy, second, by the EU strategy and the conditions for development of entrepreneurship and innovative activities, third, by the impact of cohesion policy and the orientation towards reducing the EU regional disparities, fourth, by the promotion of innovative processes in collaboration with the EU member states and regions.

The impact of the population is most affected, first, by the activities of particular groups of residents in acquisition and dissemination of ideas of innovative changes, second, by the use of residents' disposable resources for income generation, third, by residents' entrepreneurial ability and capacity, fourth, by the involvement of residents in formal and nonformal education.

Thus, in the choice of smart specialization the smart governance direction prevails with the proportion of 0.28 . Next is the smart population direction with a slightly smaller proportion of 0.26 . The third is smart economy direction with the proportion of 0.26 , while the fourth is the smart environment direction with the proportion of 0.22 . Among the first three directions the difference is only 0.02 , but the difference between the smart economy and smart environment direction is 0.04 .

Smart Development Concept of Vidzeme Region
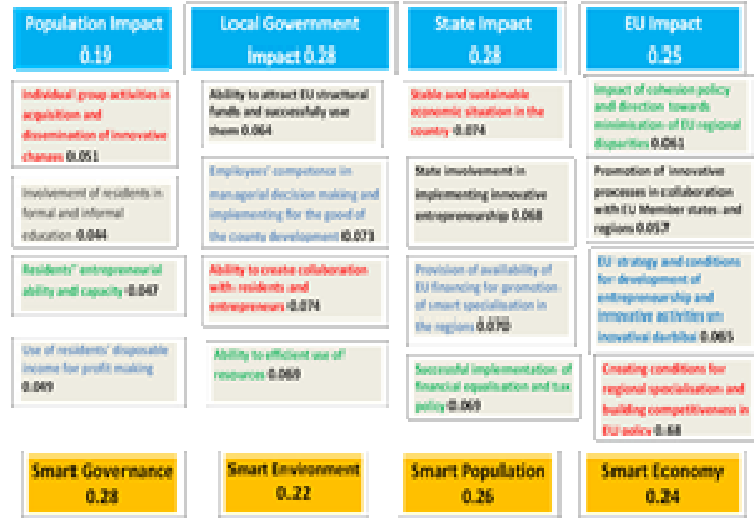

Fig 7. Smart development concept of Vidzeme region

\section{CONCLUSION}

Evaluating the published strategic and operational planning documents of Vidzeme municipalities, it can be concluded that sustainability is usually referred to as a goal in itself, a result of a certain process, although it should be mostly regarded as an evaluation mechanism for a variety of other real-life processes, and a set of tools that can determine 
whether a particular region has the smart, sustainable development prospects and to what extent.

In order to measure the impact of the population, the local government, the state and the EU policy on the smart development of Vidzeme region, the Analytic Hierarchy Process (AHP) method can be used.

The residents have indicated that in the state dimension the following indicators operate the most successfully: ensuring the availability of the EU funding, the maintenance of the legislative stability in the country. On the contrary, the least successful are: the successful operation of the financial equalization fund, earmarked subsidy offers, the development of a tax system that promotes the economic activity.

In the state dimension, the experts have recognized the following tools as significant: a stable and sustainable economic situation in the country and the provision of the availability of the EU funding for the promotion of smart specialisation in the regions.

The residents have pointed out that in the local government dimension the following indicators operate the best: the skills of a municipality or town local government to attract EU structural funds and use them successfully. In contrast, the least successful operation in the local government dimension is assigned to the ability of the local government to create favourable conditions for the activities of NGOs and other groups of society, actively involving them in the discussion and implementation of important development issues, the ability of a local government to maintain close working contacts with local businesses.

In the local government dimension, the experts have recognized the following tools as significant: the ability to establish collaboration with residents and entrepreneurs, and employees' competence in managerial decision making and implementing for the good of the municipality development, which have been evaluated by the residents as the least successfully applied instruments.

The residents have indicated that in the community dimension, the most successful operation is assigned to the interest of local residents to take part in solving practical issues of a municipality/ town by active participation, the readiness of municipality/ town residents for economic activities in order to increase personal income, activities of particular groups of residents in acquisition and dissemination of ideas of innovative changes. On the contrary, the operation is evaluated as the least successful in the following areas: the ability of municipality/ town residents to cooperate through the economic cooperation chains or even cooperatives, the readiness to accept change in work, society, environment.

In the population dimension, the experts have recognized the following tools as significant: activities of particular groups of residents in acquisition and dissemination of ideas of innovative changes, and residents' entrepreneurial ability and capacity.

In the EU dimension, the experts have acknowledged the most influential tools to be creating conditions for regional specialisation and building competitiveness in the EU policy.

The AHP hierarchy analysis shows that the local government and the state has the greatest impact on Vidzeme region smart specialization development, which is most influenced by the ability of the local government to establish collaboration with residents and entrepreneurs, and maintaining of a stable and sustainable economic situation in the country.

A significant influencing force is the EU with its most important instruments - its policy that creates conditions for region's specialization and competitiveness, and the strategy and conditions for business development and innovation.

According to the evaluation of experts, the choice of Vidzeme smart specialization is related to the smart governance direction.

\section{V.ACKNOWLEDGMENTS}

This study was supported by the National Research Program 5.2.3. "Economic Transformation, Smart Growth, Governance and Legal Framework for the State and Society for Sustainable Development - a New Approach to the Creation of a Sustainable Learning Community (EKOSOC-LV)".

\section{REFERENCES}

[1] Eiropean Commission, EIROPA 2020 EU's growth strategy Available: http://ec.europa.eu/europe2020/index_en.htm

[2] Reǵionālās attīstības likums, LR Saeima 2002), Pieejams: https://likumi.lv/doc.php?id=61002

[3] Teritorijas attīstības plānošanas likums, LR Saeima 2011, Available: https://likumi.lv/doc.php?id=238807

[4] Attīstības plānošanas sistēmas likums, LR Saeima 2008 , Available: https://likumi.lv/doc.php?id=175748

[5] Vides aizsardzības likums, LR Saeima, 2006, Available: https://likumi.lv/doc.php?id=147917

[6] Likums "Par pašvaldībām", LR Saeima, 1994, Available: https://likumi.lv/doc.php?id=57255

[7] Steurer, R., \& Hametner, M. Objectives and indicators in sustainable development strategies: similarities and variances across Europe. // Sustainable Development, 21(4). 2013, pp. 224-241.

[8] EK European Innovation Scoreboard 2016, Available: http://ec.europa.eu/growth/industry/innovation/factsfigures/scoreboards_en

[9] Wheeler, S. M., \& Beatley. T. Sustainable Urban Development Reader., Routledge. Park, 2014.

[10] Shen, L.Y., Ochoa, J.J., Shah, M.N. and Zhang, X. The application of urban sustainability indicators-A comparison between various practices. Habitat International, 35(1). 2011, pp.17-29.

[11] Engardio P., Capell K. Beyond The Green Corporation. Business week, 50. 2007, pp.1-6.

[12] Saaty T.A., Penivati K. Group Decission Making Draving out and Reconciling Differences. United States of America. 2013. 